\title{
化粧品の機能，使用感を高めるエマルション膜設計 Design of Emulsion Film for Cosmetics with High Function and Good Feeling
}

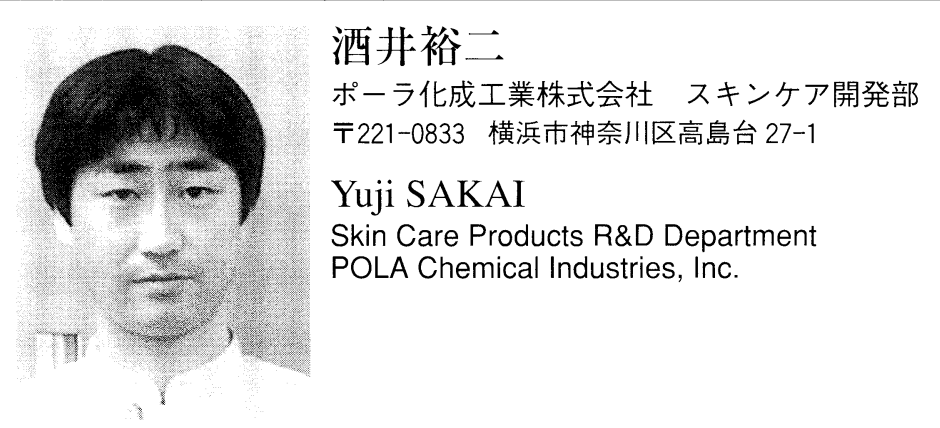

論文要旨：エマルション化粧品を皮膚上に投与すると，エマルション膜が形成される。この状態がエマル ション化粧品の保水性, 閉塞性, 使用感等に大きく影響を与えることから，エマルション膜の状態の解明を 試みた。ポリオキシエチレン系界面活性剤を用いたエマルションのエマルション膜は，エマルション滴が消 滅していた。一方，ポリグリセリン脂肪酸エステルの方は，エマルション滴が維持されていた。保水性，閉 塞性は共に良好な結果を示した。これを連用することで, 角層状態も改善した。またアルギン酸プロピレン グリコールエステルを用いたエマルション膜は, 上層に水和ゲル膜を作成した。そのため, 油相量を多くし ても，べたつき感がなく，良好な使用感を得ることができた。

\begin{abstract}
An emulsion film is formed when I apply emulsion cosmetics on skin. I tried to investigate the state of emulsion film, because this state affected the moisturizing and occlusive functions, feelings of emulsion cosmetics significantly. For emulsions used polyoxyethylene-type surfactant, droplets disappear after the film is formed, whereas used polyglycerin-type surfactants, the droplets shape is retained even. The moisturizing and occlusive functions show good results together. The stratum corneum is improved significantly after continuous use. Hydration gel film is formed in the upper side in the case of using alginic acid propylene glycol ester. Therefore I am able to get good feeling, no sticky even if oil content in emulsion is increased.
\end{abstract}

Key words：エマルション，エマルション膜，保水性，閉塞性，ポリグリセリン脂肪酸エステル，ア ルギン酸

\section{1 はじめに}

スキンケア化粧品は, 皮膚を健やかに保ち, 美しく綺 麗にするために用いる。そのためスキンケア化粧品は皮 膚に作用させるが，そのほとんどのものが，皮膚上で薄 膜の状態になる。この薄膜になったものいわゆる化粧膜 が，皮膚に対して機能，効果を発現する。しかし，化粧 品の機能を議論する際, 評価しにくいあるいは可視化し にくいとの理由で, この化粧膜について焦点を当てるこ とがほとんどできなかった。しかし最近, 測定機器が進
歩したことに伴い，この化粧膜，とりわけエマルション の薄膜であるエマルション膜の評価, 可視化が可能と なった ${ }^{1-3)}$ 。以下に，エマルション膜の状態と機能の関係 について言及する。

\section{2 保水効果と閉塞効果の両立}

\section{$2 \cdot 1$ 保水効果と閉塞効果を高めるエマルション膜設計} 乾燥, 肌荒れしている肌は, うるおいが少なく, 皮膚 からの水分蒸散量が多い。これを防ぐため，スキンケア 化粧品, とりわけエマルション状の化粧品が広く用いら れている。これらエマルション化粧品は, 概して水やポ リオールからなる親水領域と油やワックス等からなる親 
油領域からなっている。親水領域は文字通り水分を多く 含むため，皮膚へ水分を継続的に供給することができ る。この現象は一般的に保水効果と呼ばれている た親油領域は，皮膚からの水分蒸発を防ぐことができ る。この現象は一般的に閉塞効果と呼ばれている ${ }^{4,5)}$ 。そ のため，エマルション化粧品は，保水効果，閉塞効果の 両機能を合わせ持つことができる。たとえば，エマル ション中のグリセリンの配合率を高めると, 親水領域が 広がることで保水効果が高められる。一方, 油の配合率 を高めると，親油領域が広がることで閉塞効果が高めら れる。

しかし当然のことながら，エマルションの親水領域が 広がると親油領域が狭まり，逆に親油領域が広がると親 水領域は狭まる。すなわち, 保水効果と閉塞効果は拮抗 し，両機能は同時に高めにくい関係にあるといえる。ま た極性を有する油や抱水性油剤，他のポリオールを単に 配合しても，保水効果と閉塞効果を同時に高められない こと（拮抗関係）が報告されている ${ }^{4)}$ 。この点がエマル ション化粧品の機能限界の所以と考えられる。そのため たとえば，閉塞効果の高いエマルションを使用した場合 は，保水効果の高いローション等も同時に用いることが 求められる。

この課題を解決するため, われわれはエマルション膜 の構造，状態に焦点を当てた。エマルション膜は，皮膚 に接していること，前記機能を発現しているのはエマル ションではなくエマルション膜であることから，この部 分に着目することが課題解決に重要と考えた。そして, もしエマルション膜が健康な角層に似せることができた のなら（Fig. 1），エマルションの保水効果と閉塞効果を 同時に高められるのではないかとの仮説を立てた。なぜ なら健康な角層は，角層細胞の中に保湿成分が多くある ため水分をしっかり保持でき，すなわち保水効果が高 く，また細胞間脂質が強固な構造を形成しているため皮 虐内部の水分が蒸散しにくい，すなわち閉塞効果が高い ためである。そして角層の構造を鑑みて，角層細胞をエ

\section{エマルション膜}

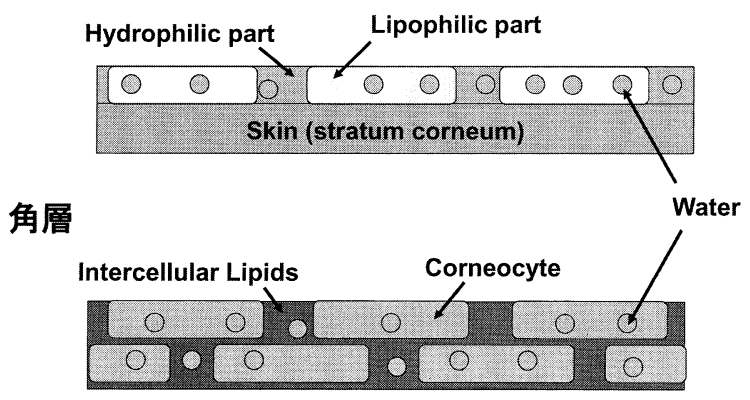

Fig. 1 高い保水効果と閉塞効果を有するエマルション膜と 健康な角層

マルション膜の親油領域，細胞間脂質をエマルション膜 の親水領域とみなし，角層細胞に水分が多くあるよう に，親油領域に水を多く分散させること，細胞間脂質が 強固であるように，親水領域を強固にすることが，保水 効果と閉塞効果の両立に効果的であると考えた。

\section{$2 \cdot 2$ 親油領域への水の分散}

エマルションの保水効果を高めるため, エマルション 膜の親油領域に水を分散させる方法を考えた。ただし， エマルション膜を直接測定するのは困難であるため，エ マルション滴中へ水を分散させる方法で検討した。まず 汎用されているポリオキシエチレン系界面活性剂を試し た結果，親油性界面活性剂および親水性の高いポリオキ シエチレン-25-ステアレート（25ES，HLB15）でも， 水を容易に油（スクワラン）へ分散することができた (Fig. 2)。ポリオキシエチレン系界面活性剤は，油に多 くモノマー分散できるため，水の通過できる道（水道） を作ってしまうと考えられる ${ }^{6)}$ 。そのため, 油にモノ マー分散しにくいポリグリセリン系界面活性剤で，水を 油に分散させる方法を改めて検討した。その結果，親水 性の高いデカグリセリンモノステアレート（10GMS， HLB14.5）は，単独では油中で水和結晶の状態になって しまったが，セタノールを効果的に混合することで，水 を容易に分散することができた。この系での油の閉塞効 果を確認した結果，閉塞効果が低下していないことも分 かった。セタノール自身は水を分散させられないことか ら，水道ができなかったと考えられる。

\section{$2 \cdot 3$ 親水領域の構造強化}

次にエマルションの閉塞効果を高めるため, エマル ション膜の親水領域の構造を強化させる方法を検討し た。ただし，エマルション膜の親水領域の性質を直接測 定することは困難であるため，エマルションの親水部分 すなわち連続相の構造に焦点を当てた。まず処方は同じ であるが，乳化法を変えた 2 種類のエマルションを作成 した。一方は機械力を用いてエマルションを作成したた め, 親水領域の構造性が弱く, エマルションは流動し た。もう一方は D 相乳化法 ${ }^{7)}$ によりエマルションを作成

(a)

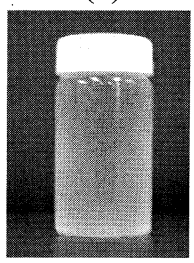

(b)

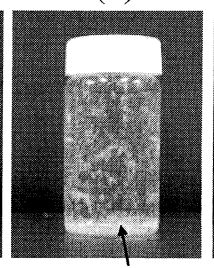

Hydrated crystal (c)

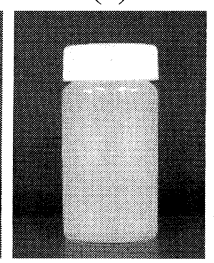

Fig. 2 各分散剤によるスクワラン中への水の分散状態（水 $1.5 \mathrm{wt} \%$ ) (a) $1 \mathrm{wt} \%$ 25ES, (b) $1 \mathrm{wt} \% 10 \mathrm{GMS}$, (c) $1 \mathrm{wt} \%$ 10GMS, 2 wt \% セタノール, (d) 2 wt $\%$ セタノール 


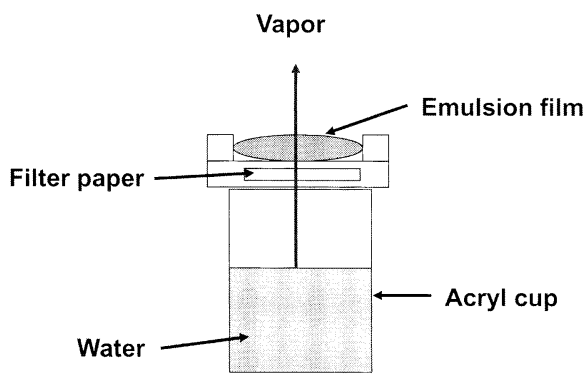

Fig. 3 カップ法

したため, 親水領域の構造性が強く, エマルションは流 動しなかった。

次に，この両エマルションの閉塞効果を測定した。エ マルション膜の閉塞効果は，カップ法により測定した (Fig. 3)。カップ法とは, 一定量の水を注いだアクリル カップの上部をろ紙で封をして，この部分にサンプルを 塗布し, $30^{\circ} \mathrm{C}$, 湿度 $30 \%$ 下に放置後，水分蒸散量を測 定して，その抑制効果を評価する方法である。経過時間 と水分蒸散量は直線関係にあるため，この傾きを水分蒸 散抑制指数（WLI）と定義した（Fig. 4）。結果は，構造 性の高いエマルションの方が常に低く, 閉塞効果が高い ことが分かった（Fig. 5)。界面活性剤単独の場合, 微視 的粘性すなわち流動性が高いと水分蒸散しやすいとの報 告があり ${ }^{8)}$ ，本実験を支持するものである。

そこで前検討から選択されたポリグリセリン系界面活 性剂を用いて，エマルションの連続相の構造化を試み

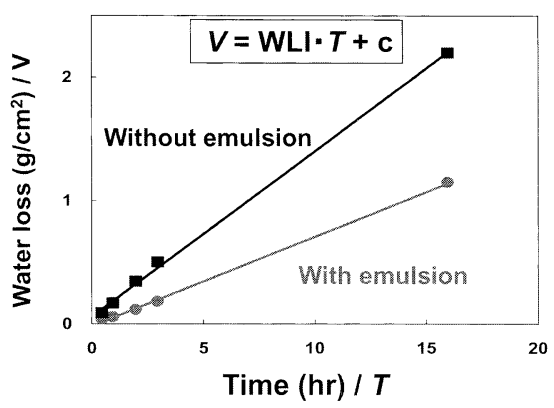

Fig. 4 カップからの水分蒸散の経時変化

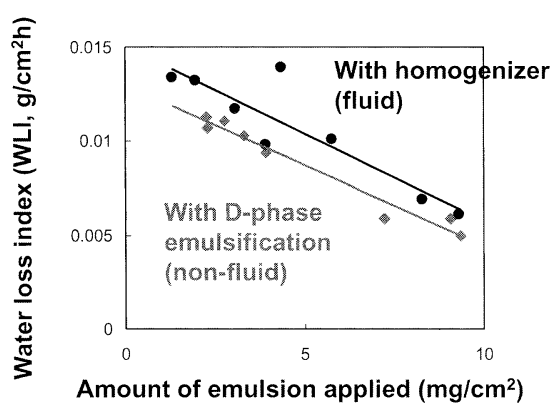

Fig. 5 異なる乳化法により調製したエマルションの水分蒸 散量 (25ES で調製)
Table 1 エマルションの連続相に及ぼす親水性界面活性剂の 効果 (1) 流動しない, (2) 流動する

\begin{tabular}{lcc}
\multicolumn{1}{c}{ Hydrophilic surfactant } & 10GMS & $(25 \mathrm{ES})$ \\
\hline Without hydrophilic surfactant & 2 & 1 \\
Sucrose stearate & 2 & 1 \\
PEG-45 stearate & 2 & 1 \\
PEG-100 hydrogeneted castol oil & 2 & 1 \\
PEG-150 distearate & 2 & 2 \\
PEG-150 stearate & 2 & 1 \\
PPS & 1 & 1
\end{tabular}

$0.5 \mathrm{wt} \%$ Hydrophilic surfactant, $1.6 \mathrm{wt} \%$ 10GMS,

$2 \mathrm{wt} \%$ GMS, 3 wt $\%$ butylene glycol, 3 wt $\%$ cetyl alcohol, $14 \mathrm{wt} \%$ squalane, $8 \mathrm{wt} \%$ trioctanoin, water (the residue).

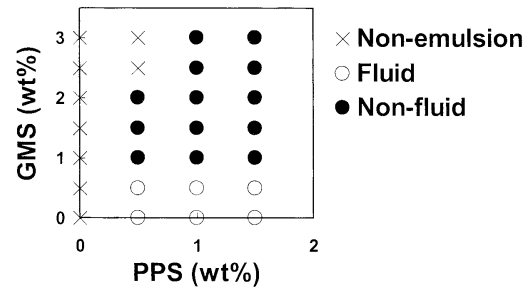

Fig. 6 流動しない（親水領域が強固）エマルションの領域 (1.6 wt\% 10GMS)

た。しかしポリグリセリン系界面活性剤は，連続相に液 晶等の構造を作りにくいことが分かった。化粧品の処方 化において，O/W 型エマルションの連続相を構造化さ せる方法としては，界面活性剂や油，固型油，高級アル コール，増粘剤等を増量する方法がある。しかし，これ らはエマルション化粧品としての品質，皮膚安全性，使 用性に問題がでてくる可能性がある。そこで，HLB 值 が非常に高い親水性界面活性剂が連続相の構造化に大き く寄与すると考え，10GMS とグリセロールモノステア レート（GMS）をベースに，親水性界面活性剤の探索を 行った。その結果，ポリグリセロール(13) ポリオキシ ブチレン（14）ステアリルエーテル（PPS）を活用する ことで，エマルションの流動性を抑えることができた (Table 1)。またその領域は，Fig. 6 に示すと抢りであっ た。

この要因を探るため，X 線小角散乱法により，エマル ションの構造を調べた。その結果，PPS 配合系のみ 62 Aの散乱ピークが確認された（Fig. 7)。PPSの分子鎖長 は，130〜180 ̊であることから，このピークはPPS で はなく，GMSの由来と考えられた。つまりPPSは GMSの液晶構造を保護したと思われる。

\section{$2 \cdot 4$ 保水効果と閉塞効果の評価}

そこで, Table 2 に示すような 2 種のエマルション, すなわち本検討により開発されたエマルション $\mathrm{A}$ と， これに類似しているが本研究の結果を反映させていない 従来のエマルション B を調製して，エマルション膜の保 


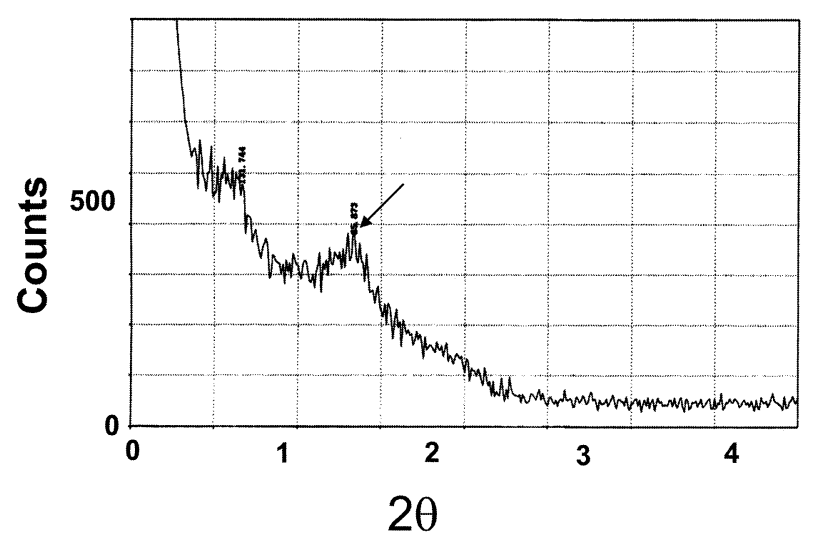

Fig. 7 エマルションの小角 X 線パターン (1.6 wt\% 10GMS, $2.5 \mathrm{wt} \%$ GMS, $1.5 \mathrm{wt} \%$ PPS)

Table 2 新エマルションと従来のエマルションの組成 (a) 新 エマルション A, D 相乳化で調整, (b) 従来のエマ ルション B，ホモミキサー使用

\begin{tabular}{|c|c|c|}
\hline Ingredient & $\mathrm{a}$ & $\mathrm{b}(\mathrm{wt} \%)$ \\
\hline GMS & 1.5 & 2.0 \\
\hline $25 \mathrm{ES}$ & 0.0 & 2.0 \\
\hline 10GMS & 2.0 & 0.0 \\
\hline PPS & 0.5 & 0.0 \\
\hline butylene glycol & 3.0 & 3.0 \\
\hline cetyl alcohol & 3.0 & 0.0 \\
\hline squalane & 14.0 & 17.0 \\
\hline trioctanoin & 8.0 & 8.0 \\
\hline glycerin & 5.0 & 5.0 \\
\hline water & 63.0 & 63.0 \\
\hline
\end{tabular}

水効果と閉塞効果を測定した。閉塞効果においては, 前 記したWLI はエマルションの塗布量により值が異なる ため, 新たに固有膜閉塞指数（IFO）を以下のように定 義した。

$$
\mathrm{IFO}=(\mathrm{x} / \mathrm{y}) 1 / \mathrm{z}
$$

$\mathrm{x}$ : エマルションを塗布していない時の $\mathrm{WLI}\left(\mathrm{g} / \mathrm{cm}^{2} \cdot \mathrm{h}\right)$ $\mathrm{y}$ : エマルションを塗布した時の $\mathrm{WLI}\left(\mathrm{g} / \mathrm{cm}^{2} \cdot \mathrm{h}\right)$ $\mathrm{z}:$ 塗布したエマルションの重量 $\left(\mathrm{g} / \mathrm{cm}^{2}\right)$

またエマルション膜の保水効果は，すりガラス表面に サンプルを塗布して， $30^{\circ} \mathrm{C}$ ，湿度 $30 \%$ 下に放置後，そ の重量を測定し含水率を算出することで評価した。しか し，この方法は，含水率が時間に依存すること，エマル ション膜の特性以外の要因が反映されてしまう点が課題 であった。そこでエマルション膜の含水率を長時間にわ たり測定し，0 時間に外抻することでこの課題を解決し た。これを固有膜保水指数（IFM）と以下のように定義 した (Fig. 8)。

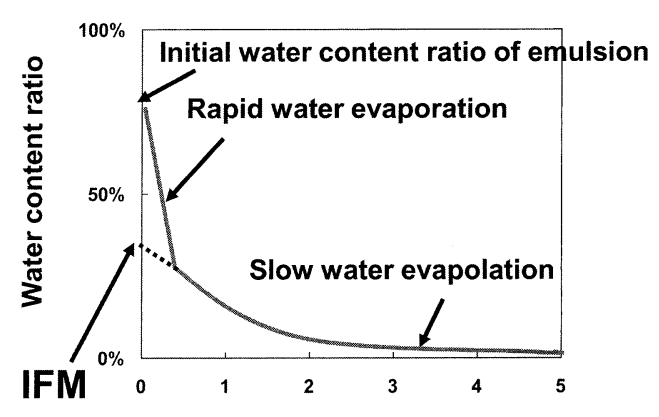

Fig. 8 エマルション膜に含まれる水分量の変化

$\mathrm{IFM}=\mathrm{W} \cdot \exp (\mathrm{aT})$

$\mathrm{W}$ ：エマルション膜中の水分含有比

$\mathrm{T}$ ：エマルション塗布経過時間 (分)

$\mathrm{a}$ : 常数

その結果（Fig. 9), 従来エマルション B のエマルショ ン膜の IFM が 14.4 , 新エマルション A のエマルション 膜は 17.5 であり，約 $22 \%$ 向上していた。一方従来エマ ルション B 膜の IFO は 1.11，新エマルション A 膜は 1.46 であり，約 $32 \%$ 向上していた。つまり保水効果と閉 塞効果を同時に高めることに成功した。ただし，従来の エマルションと同様に，油の配合割合を高めると閉塞効 果が高くなり保水効果は低下する，またグリセリンの配 合割合を高めると保水効果が高くなり閉塞効果が低くな る点については，同様の傾向であった。

\section{$2 \cdot 5$ エマルション膜の状態観察}

この結果を化粧膜状態から考察するため，新エマル ション $\mathrm{A}$ と従来エマルション $\mathrm{B}$ の膜状態をレーザー顕 微鏡により観察した。その結果，新エマルション $\mathrm{A}$ 膜 は，エマルション滴らしきものが，キメ細かく残存して いる状態が観察された（Fig. 10）。一方，従来エマル ション B 膜は，エマルション滴らしきものはまったく観 察されなかった。この状態を 3 次元解析した結果 (Fig. 11), 従来エマルション B 膜と比較して新エマルション A 膜は，起伏が高く，起伏幅が狭かった（Table 3）。ま

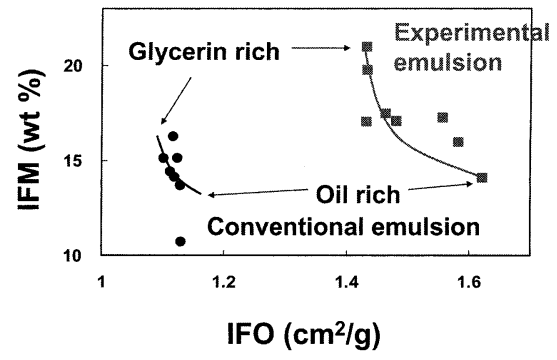

Fig. 9 新エマルションと従来エマルションの IFM および IFO（スクワランおよびグリセリン量を変化させてい る) 
(a)

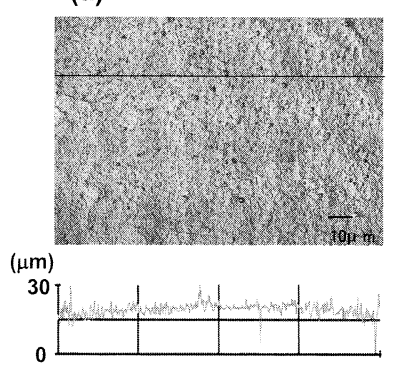

(b)

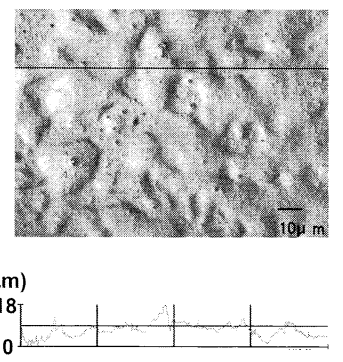

Fig. 10 各エマルション膜のレーザー顕微鏡像と断面起伏困 (塗布 30 分後) (a) 新エマルション A，(b)従来エマル ション B

(a)

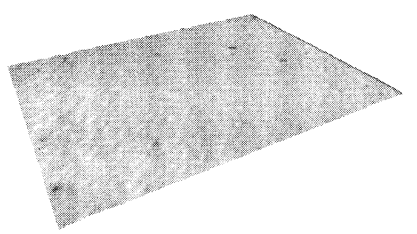

(b)

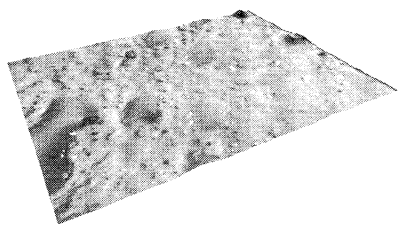

Fig. 11 各エマルション膜の 3D 像 (塗布 30 分後) (a) 新エマ ルション $\mathrm{A},(\mathrm{b})$ 従来エマルション $\mathrm{B}$

Table 3 各エマルション膜の $3 \mathrm{D}$ 解析值 (a) 新エマルション $\mathrm{A},(\mathrm{b})$ 従来のエマルション B

\begin{tabular}{lcc}
\hline & $\mathrm{a}$ & $\mathrm{b}$ \\
\hline Area $\left(\mathrm{mm}^{2}\right)$ & 1.51 & 1.51 \\
Surface area $\left(\mathrm{mm}^{2}\right)$ & 7.85 & 3.03 \\
Surface area / area & 5.21 & 2.01 \\
Average height of undulation $(\mu \mathrm{m})$ & 4.08 & 2.83 \\
Average space of undulation $(\mu \mathrm{m})$ & 14.2 & 19.5 \\
\hline
\end{tabular}

た表面積は非常に広いことも分かった。これは，両エマ ルション膜の構造, 状態が大きく異なっていることを如 実に示している。

\section{$2 \cdot 6$ 連用評価}

最後に, 新エマルションの皮虐（角層）への効果を確 認した。試作品の連用評価では，女性パネラー 44 名が, 新エマルションを約 1 カ月間, 全顔に使用した。その使 用前後において，左右頬部の角層をテープストリッピン グした。これを顕微鏡観察下で，肌のうるおいの指標と なる重層剥離レベル，バリアー機能の指標となる角層細 胞の並び方を，目視により評価した9)。

その結果, 重層剥離レベルの平均評点が 2.75 から 2.32 へと有意に低下 (改善) した（Fig. 12，13）。また角層細 胞の並び方の平均評点も 2.93 から 2.68 へと有意に低下 (改善) した（Fig. 14，15）。新エマルションを使用して いない同時期の両項目の変化は, 0.09 と 0.02 の低下で あったことから, 新エマルションは, 角層に対して非常 に有益であると考元られる。

Before

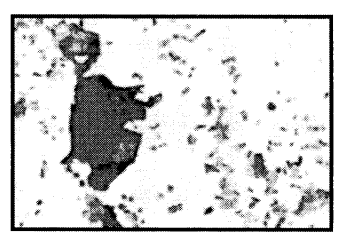

After

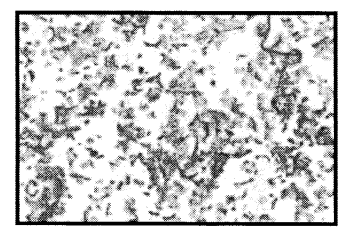

Fig. 12 連用評価前後の角層の重層剥離状態の変化

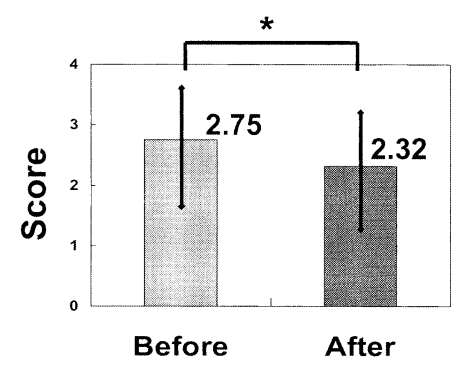

Fig. 13 連用評価前後の角層の重層剥離レベルの平均変化

Before

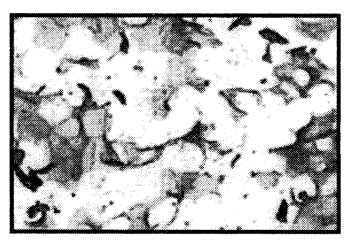

Fig. 14 連用評価前後の角層細胞の並び方の変化

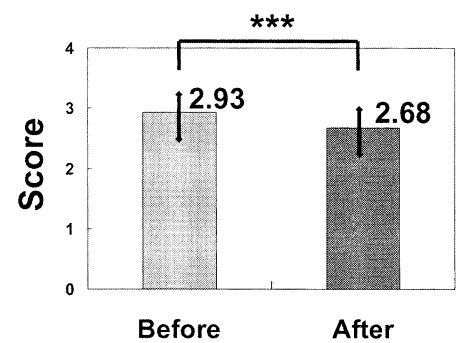

Fig. 15 連用評価前後の角層細胞の並び方の平均変化

\section{3 使用感の向上}

\section{$3 \cdot 1$ 閉塞効果と使用感を高めるエマルション膜設計}

概してエマルションは，油の配合量を多くすることで 閉塞効果が高まる。しかしその反面，「べたつく」，「な めらかでない」といった使用感に課題がある。これは, 油の使用感がそのまま反映された結果である。そこで, 本課題を解決すべく, ここでもエマルション膜に焦点を あてた。すなわち上層にベタッキ感を抑える膜たとえば 水和ゲル膜，下層に閉塞性が高い油膜を有する 3 次元的 な膜構造，すなわち 2 重構造膜（Fig. 16）を実現できれ ば，閉塞性と使用感を両立できると考えた ${ }^{10)} 。$

\section{$3 \cdot 2$ 乳化剤の検討}

エマルション膜の構造に大きく影響する因子として, 
ベたつかない

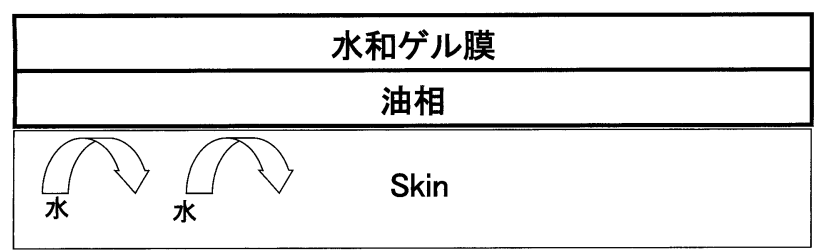

高い閉塞性

Fig. 16 エマルション膜設計 (2 重構造膜)

前記内容と同じく乳化剂が挙げられる。そこで乳化剤の スクリーニングを行った。ポリオキシエチレン系界面活 性剤, ポリグリセリン脂肪酸エステル, acrylates/c 10-30 alkyl acrylate crosspolymer 用いたエマルショ ンのエマルショシ膜は, 全体が均一でゲル状の外観を呈 し, 水和ゲル膜と油膜を有する 2 重構造膜は形成しな かった。これは, 乳化剤の親油基が大きいため, エマル ション膜の水と油の分離が起きなかったこと（油水界面 も強固）が原因と考えられる。また乳化剂が低分子ある いは水酸基が少ないため，水和ゲル膜が形成しにくかっ たとも推測される。そこで, 乳化剤の親油基を小さくし つつも乳化が可能であり, 水酸基を多く有し水和ゲル膜 を形成できる素材を探索した。その結果，アルギン酸プ ロピレングリコールエステル（アルギン酸 PGA, Fig. 17, 18）が見出された。またアルギン酸 PGA は, 乳化し にくい極性油やシリコーン油, フッ素系油も乳化が可能 であった。

\section{$3 \cdot 3$ アルギン酸 PGA を活用したエマルションの安定化} ただし，このアルギン酸 PGA は親油基が小さいこと から, 乳化させた油滴の表面の膜（界面膜）を強固にす ることが困難なため, 高温下や経時変化による油滴同士 の凝集・合一を防ぐことができなかった。エマルション の安定性を高める場合, カルボマーや多糖類を用いて粘 度を高くすることでエマルション滴の凝集・合一を防ぐ 方法が知られている。しかし本ケースにおいては，この 方法ではエマルション滴の合一を抑制することはできな かった。そこでわれわれは, 従来の粘度アップによる安 定化とは異なり，エマルション滴同士を架橋させること で，物理的に合一しにくくさせる新たな方法で安定化を
試みた。架橋剤としては，エマルション滴に吸着できる 高分子およびこの高分子同士を架橋できるものが必要で ある。スクリーニングの結果，アルギン酸ナトリウムと 塩化カルシウムが架橋構造形成には好ましく, エマル ション安定化に効果的であった。すなわち，アルギン酸 PGA で乳化した油滴の表面にアルギン酸を吸着させ, 塩化カルシウムで他の油滴表面にあるアルギン酸とつな ぎ合わす。この結果, 油滴の運動性が抑制され, 凝集 ・ 合一を防ぐことが可能になったと考えられる（Fig. 19）。 また架橋構造の結果, エマルション滴の分散状態は, 従 来の安定なエマルションでは見られない不均一な状態で あった（Fig. 20）。

\section{$3 \cdot 4$ エマルション膜の状態と使用性評価}

このアルギン酸系エマルションの塗布した状態をマイ

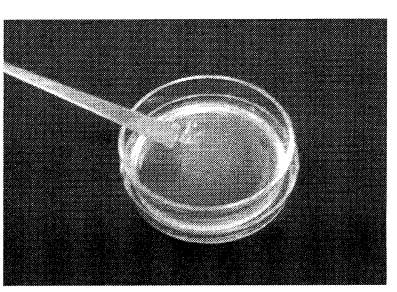

POE系エマルション

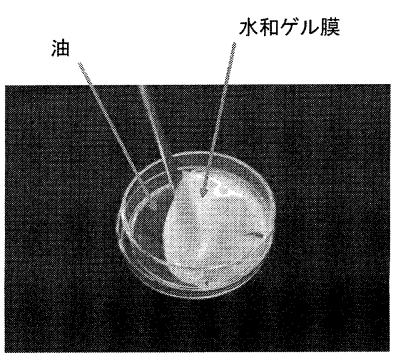

アルギン酸系エマルション
Fig. 18 アルギン酸系エマルションのエマルション膜状態

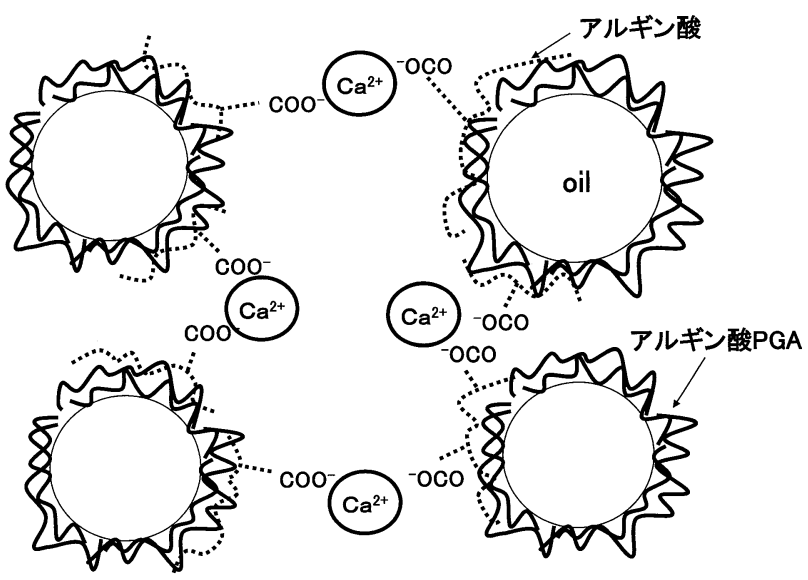

Fig. 19 アルギン酸系エマルションの安定化メカニズム

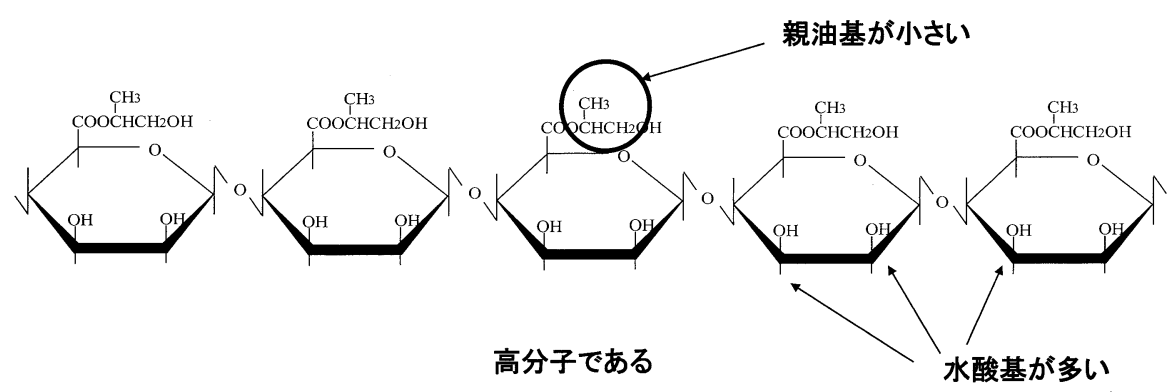

Fig. 17 アルギン酸 PGA の化学構造式 


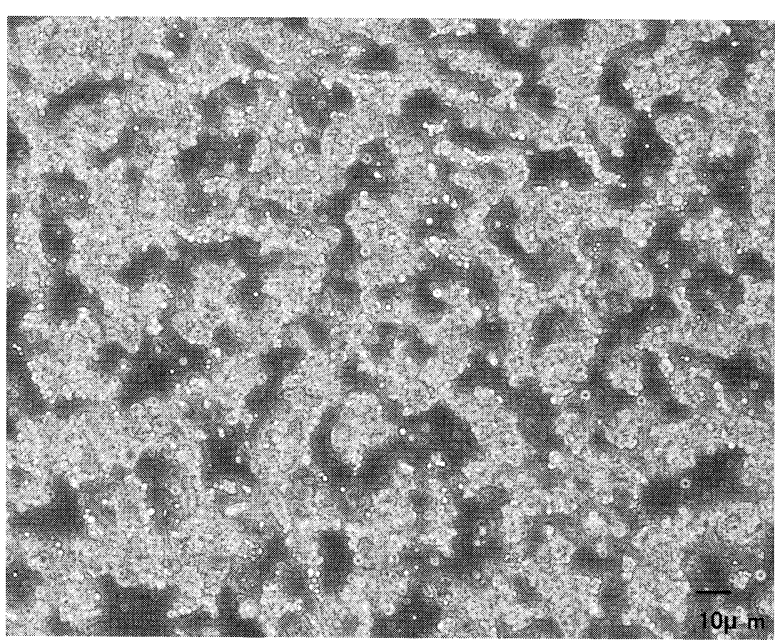

Fig. 20 アルギン酸系エマルションの顕微鏡像

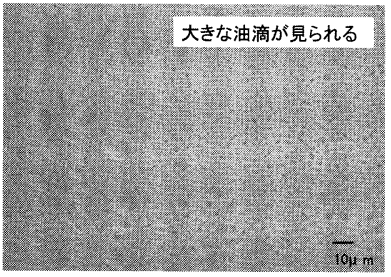

POE系エマルション

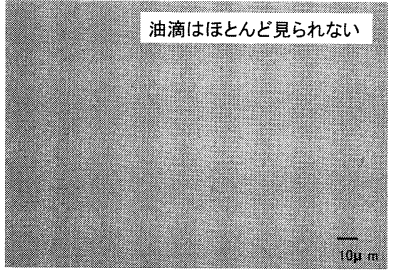

アルギン酸系エマルション
Fig. 21 各エマルション膜の透過型マイクロスコープ像

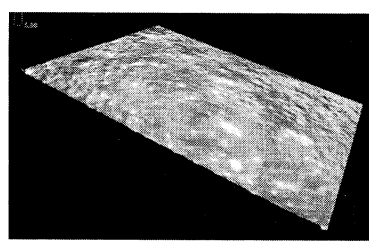

POE系エマルション

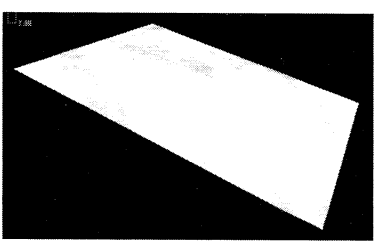

アルギン酸系エマルション
Fig. 22 各エマルション膜のレーザー顕微鏡像

クロスコープで観察した結果, エマルション滴が観察さ れないことが分かった（Fig. 21）。これは薄膜化に伴い 架橋構造が崩れ，エマルション滴が完全に崩壊したこと を示している。また従来の POE 系乳化剂を用いたエマ ルションは, エマルション膜状態でもエマルション粒子 が確認された。これは，エマルション滴の界面の界面活 性剂の配向性が高く，すなわち界面膜が強く，薄膜化し ても完全にはエマルションが崩壊できなかったためと考 えられる。一方，レーザー顕微鏡で観察した結果，従来 のエマルション膜に比べ非常になめらかな表面状態を形 成していることが分かった（Fig. 22）。これはエマル ション膜の上層に水和ゲル膜が形成されたためである。 また官能評価を実施した結果，「べたつきがない」，「な めらかさを感じる」との項目で，非常に良好であった (Fig. 23, 24)。これはエマルション膜の上層に形成した 水和ゲル膜が，油の使用感の悪さをカバーできたためで

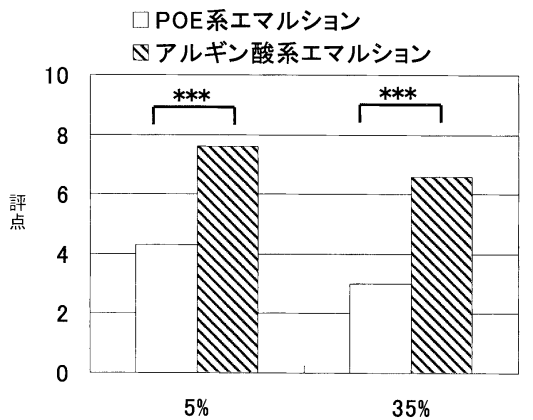

Fig. 23 エマルションの使用性評価（べたつきのなさ）

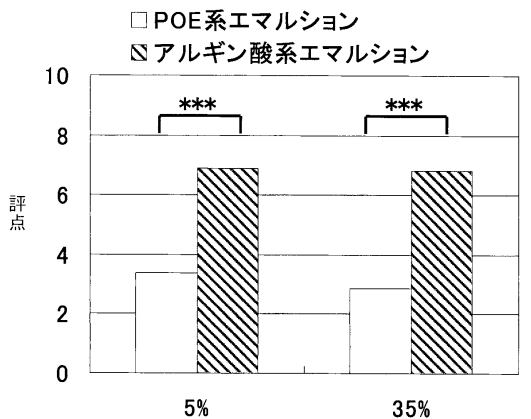

Fig. 24 エマルションの使用性評価（なめらかさ）

ある。とりわけ, 油の量を増加させたエマルションで も，この 2 項目については高い評価であり，特筆すべき 点である。

\section{4 おわりに}

エマルション化粧品を設計，処方化するにあたり，従 来は皮膚に塗布されているエマルションの状態，すなわ ちエマルション膜に対して，あまり焦点を当てていな かった。しかし本研究により, エマルション膜の構造を 意識しながら, エマルションを処方化することで, エマ ルションの機能性向上, あるいは課題点を解決させるこ とが可能となった。本研究が, 今後のエマルション研究 あるいは化粧品開発に寄与できれば幸いである。

\section{文献}

1) Y. Sakai \& M. Suzuki, IFSCC Magazine, 9, 23-8 (2006).

2) Y. Sakai \& M. Suzuki, J. Soc. Cosmet. Chem. Jpn., 40, 95-104 (2006).

3) Y. Sakai \& M. Suzuki, Fragrance J., 10, 25-31 (2005).

4) S. Nishiyama, H. Komatsu \& M. Tanaka, J. Soc. Cosmet. Chem. Jpn., 16, 136-43 (1983).

5) A.M. Kligman, Cosmetics Toiletries, 93, 27-35 (1979).

6) M. Fukuda \& K. Shinoda, J. Jpn. Oil Chem. Soc., 48, 587-94 (1999).

7) H. Sagitani, Y. Ikeda \& Y. Ogo, J. Jpn. Oil Chem. Soc., 33, 156-61 (1984).

8) Y. Aoki \& Y. Sumida, $22^{\text {nd }}$ IFSCC Congress, Edinburgh, Podium, p.38 (2002).

9) N. Kashibuchi \& Y. Muramatsu, J. Soc. Cosmet. Chem. 
Jpn., 23, 55-7 (1989).

10) M. Suzuki \& Y. Sakai, $24^{\text {nd }}$ IFSCC Congress Osaka Jpn., Poster 202 (2006). 